\title{
The problem of hate crimes in the United States of America
}

\begin{abstract}
The aim of this article is to draw attention to an issue that has a long history: the problem of hate crimes in the United States of America. There is no doubt that hate crimes are the type of crime that attack the very principle of individuality that is an entitlement under the equal protection of the law (in the U.S.). Bearing the foregoing in mind the above, and that the number of such crime has increased at an alarming rate, this article describes and discusses types of hate crimes such as: Racist and Religious Hate Crimes, Sexual Orientation-Based Hate Crimes and Disability Hate Crimes as an extended projection of the analysis, several solutions have been proposed to mitigate tensions and combat the prevalence and severity of hate crime in all its forms.
\end{abstract}

Keywords: hate crime, disability, sexual motivation, religion, race

Hate crime is different on such an elementary level from other crimes. I didn't realize that until I actually was part of one. You actually have to be a part of it to understand that the fear created by that crime doesn't come from an ordinary - from a crime that's not a hate crime. Hate crimes are committed to terrorize a collection of people, not an individual. Judy Shepard (mother of Matthew Shepard, quoted in Dailey, 2009)

\section{Introduction}

Hate crime has a longer history in the United States than in other Western democracies. ${ }^{1}$ The term hate crime first emerged in United States

${ }^{1}$ M.B. Barka: Religion, Religious Fanaticism and Hate Crimes in the United States. "Revue française d'études américaines” 2006, no. 110 (4), pp. 107 ff. 
at the beginning of 1980s. ${ }^{2}$ Since the Washington and Oregon legislatures first passed hate-crime statutes in the early 1980s, 47 states have passed at least one piece of legislation to address hate- and bias-motivated crime in some way. ${ }^{3}$

Most of the authors define "hate crime" as an offense in which the victim is targeted because of their actual (or perceived) race, disability, color, religion or sexual orientation. ${ }^{4}$ It is worth noting that the popularization of this generic term, which encompasses racist, anti-Semitic, sexist and homophobic attacks, has led many scholars to observe and study different manifestations of bias-motivated aggression as a unique analytic and conceptual category. In response to what most viewed as an escalation of hate crimes leading to distrust and intergroup tension, lawmakers not just in United States but also in the United Kingdom, first introduced the category of hate crimes into criminal law and judicial practice, and then criminologists began defining this term. There are authors who argue that hate crimes are difficult to define, measure, or even to explain. ${ }^{5}$ Some commentators believe that the term "hate crime" is loaded with dilemmas and difficulties. In fact, the designation is often used very broadly, encompassing any hate-crime act against the victim. ${ }^{6}$ Other authors, in extreme cases, interpret this term as genocide, ethnic cleansing and also serial homicide. Other aspects of this phenomenon encompass homicide as well as attacks. Incidents of abuse, vandalism, and threats that jeopardize the victims' quality of life are considered less serious offenses. ${ }^{7}$

2 The other name for "hate crime" is "bias crime" perhaps because it accurately emphasizes that such offenses often arise out of prejudice toward an individual or a group of individuals. R.M. DANCYGIER, D.P. GREEN: Hate Crime. In: The SAGE Handbook of Prejudice, Stereotyping and Discrimination. Eds. J.F. Dovidio, M. Hewstone, P. Glick, V.M. Esses. London, California, New Delhi, Singapore 2010, p. 295; D.P. GreEN, L.H. McFalls, J.K. Smith: Hate Crime: An Emergent Research Agenda. “Annual Review of Sociology" 2001, no. 27 (1), p. 480.

${ }^{3}$ M. SHIVELY: Study of Literature and Legislation on Hate Crime in America. Analytic Support Program Contract. Washington, D.C. 2000, p. 2.

${ }^{4}$ However, definitions can vary from state to state; they vary from broad to narrow, and from emphasizing the social identity of the victim, to the perpetrator's motivations. K. Sun: The legal definition of hate crime and the hate offender's distorted cognitions. "Issues in Mental Health Nursing" 2006, no. 27 (6), p. 597; J.B. JacoBs, J.S. HenrY: The social construction of a hate crime epidemic. "The Journal of Criminal Law \& Criminology" 1996, no. 2 (86), p. 366; C. Petrosino: Connecting the past to the future: hate crime in America. "Journal of Contemporary Criminal Justice" 1999, no. 15 (1), pp. 22 ff.

${ }^{5}$ One of the authors is D.P. GreEn. See V. LaLI: Hate Crimes. Theoretical paradigm. "Defondology" 2016, no. 37-38, p. 35.

${ }^{6}$ One such author is B. Perry. Ibidem, p. 35.

7 This is the opinion of Donald P. Green and H. Croall, D. Wall. Ibidem, p. 35. 
Many years ago, the National Law Journal noted that the 1990s may go down in history as "the decade of hate - or at least - of hate crime." Despite a well-documented history of violence directed at minorities, during the 1980s and 1990s multiple social movements began to identify and address the problem of discriminatory violence directed at minorities: not just federal and state, but also local governments instituted task forces and commissions to analyze the issue; legislative campaigns sprang up at every level of government; prosecutors and law enforcement developed special training policies and specialized enforcement units; new sentencing rules and categories of criminal behavior were established by law; scholarly commentary and social science research exploded on the topic; and the United States Supreme Court weighed in with its analysis of the laws in three highly controversial cases. As a result of such activities, criminal conduct that was once undistinguished from ordinary crime has been parsed out, redefined, and condemned more harshly than before. And "hate crime" has secured a place in the American political as well as legal landscape.

In the last three decades almost every state in the United States has adopted at least one hate-crime statute that simultaneously recognizes, defines, and responds to discriminatory violence. Hate-crime statutes have taken many forms throughout the United States (statutes proscribing criminal penalties for civil rights violations; specific "ethnic intimidation" and "malicious harassment" statutes; and provisions in previously enacted statutes for enhanced penalties if an extant crime is committed for bias or prejudicial reasons). These laws specify provisions for race, religion, national origin, sexual orientation, age, disability, color, ethnicity, ancestry, gender, creed, marital status, political affiliation, age, involvement in civil or human rights, and armed service personnel. In addition, a few states have adopted statutes that require authorities to collect data on bias-motivated crimes; prohibit the undertaking of paramilitary training; mandate law enforcement training; specify parental liability; and provide for victim compensation. Finally, many states have statutes that prohibit the interference with or disturbance of religious worship, institutional vandalism and the desecration or the defacement of religious objects, cross burning, the wearing of hoods or masks, the formation of secret societies, and the distribution of publications and advertisements designed to harass select groups of individuals. ${ }^{8}$ Across the United States of America, state hate-crime laws vary immensely in their wording. Some

8 R. Grattet, V. Jenness: Examining the Boundaries of Hate Crime Law: Disabilities and the Dilemma of Difference. "Journal of Criminal Law and Criminology" 2001, no. 93 (3), pp. 658-660. 
laws employ a language associated with the Civil Rights movement, ${ }^{9}$ some states employ the language of ethnic intimidation or malicious harassment ${ }^{10}$ and some statutes simply increase the penalty for committing listed crime if the defendant committed a criminal act that "evidences" or "demonstrates" prejudice or bigotry based on the victim's real or imagined membership in a legally-recognized protected status. ${ }^{11}$

Following the states' lead, the United States Congress has passed three laws specifically designed to address bias-motivated violence, while continuing to consider additional legislation. In 1990, President George H.W. Bush signed the Hate Crime Statistics Act, which requires the Attorney General to collect statistical data on "crimes that manifest evidence of prejudice based on religion, sexual orientation, or ethnicity, including where appropriate the crimes of murder, non-negligent manslaughter, rape, forcible rape, aggravated assault, simple assault, intimidation, arson and destruction, damage or vandalism of property." Four years later, in 1994, Congress passed two more hate-crime laws. The Violence Against Women Act specifies that "all persons within the United States shall have the right to be free from crimes of violence motivated by gender." In the same year, Congress passed the Hate Crimes Sentencing Enhancement Act. This law identifies eight predicate crimes: murder, non-negligent manslaughter, simple assault, forcible rape, aggravated assault, intimi-

9 For example, in 1987, California adopted an "Interference with Exercise of Civil Rights" statute that states: "No person, whether or not acting under the color of law, shall by force or threat of force, willfully injure, intimidate, interfere with, oppress, or threaten any other person in the free exercise or enjoyment of any right or privilege secured to him or her by the constitution or laws of this state or by the Constitution or the laws of the United States because of the other person's race, color, religion, ancestry, national origin, or sexual orientation." Ibidem, p. 660.

10 "It shall be unlawful for any person, maliciously and with the specific intent to intimidate or harass another person because of that person's race, color, religion, ancestry, or national origin to: (a) Cause physical injury to another person; or (b) Damage, destroy, or deface any real or personal property of another person; or (c) Threaten, by word or act, to do the acts prohibited if there is reasonable cause to believe that any of the acts described in subsections (a) and (b) of this section will occur. For purposes of this section, 'deface' shall include, but not be limited to, cross-burnings, or the placing of any word or symbol commonly associated with racial, religious, or ethnic terrorism on the property of another person without his or her permission." Ibidem, pp. 660-661.

${ }^{11}$ For example, Montana in the year 1989 adopted a "Sentence Enhancement" law that states: "A person who has been found guilty of any offense, except malicious intimidation or harassment, that was committed because of the victim's race, creed, religion, color, national origin, or involvement in civil rights or human rights activities or that involved damage, destruction, or attempted destruction of a building regularly used for religious worship, in addition to the punishment provided for commission of the offense, may be sentenced to a term of imprisonment of not less than 2 years or more than 10 years." Ibidem, p. 661. 
dation, arson, and destruction, damage, or vandalism of property - for which judges are allowed to enhance penalties of "not less than three offense levels for offenses that the finder-of-fact at trial determines beyond a reasonable doubt are hate crimes." What is important, for the purposes of this law, is that "hate crime" is defined as criminal conduct wherein "the defendant intentionally selected a specific victim or property as the object of the offense because of their actual or perceived race, national origin, color, religion, ethnicity, gender, disability, or sexual orientation." Although formally broad in its scope, this law addresses only those hate crimes that take place on federal lands and properties. Then finally, the Hate Crimes Prevention Act was introduced in the Senate and the House of Representatives. ${ }^{12}$ It is worth mentioning that despite variation in their wording and content, criminal hate-crime statutes are laws that criminalize, or further criminalize, activities motivated by bias toward individuals or groups because of their real or imagined characteristics. ${ }^{13}$

There are no doubts that hate crimes have been the subject of comments and research by experts in various fields. ${ }^{14}$ Directed against individuals and groups alike, hate crimes include a wide variety of criminal behavior like: discrimination, intimidation, harassment, vandalism, assault, and murder - vastly different in their severity and in their impact on the broader community. Not only do they share a common foundation in hatred and bigotry, but they also tend to be more violent than other crimes: 74 percent result in physical injury, as opposed to 29 percent of non-hate crimes. Over the past few years, the number of hate crimes has increased at an alarming rate. ${ }^{15}$ These kinds of violent acts have become a growing threat to the well-being of society, not just on the college campus or in the workplace, but also in residential areas. ${ }^{16}$

12 Whether or not acting under the color of law, willfully causing bodily injury to any person or, through the use of fire, firearm, or explosive device, attempting to causing such injury, because of the actual or perceived: (1) race, color, religion, or national origin of any person; and (2) religion, gender, sexual orientation, or disability of any person, where in connection with the offense, the defendant or the victim travels in interstate or foreign commerce, uses a facility or instrumentality of interstate or foreign commerce, or engages in any activity affecting interstate or foreign commerce, or where the offense is in or affects interstate or foreign so commerce." Ibidem, pp. 661, 662, 665.

${ }^{13}$ Ibidem, p. 666.

${ }^{14}$ H. Hitman, D. Harel: Hate Crimes-Methodological, Theoretical \& Empirical Difficulties-A Pragmatic \& Legal Overview. “Cultural and Religious Studies" 2016, no. 1, p. 2.

15 M.B. BARKa: Religion..., pp. $107 \mathrm{ff}$.

16 This is the opinion of criminologists: Jack Levin and Jack McDevitt. M.B. BARKA: Religion..., pp. 107 ff. 
The first American law involving hate crimes was the 1964 Federal Civil Rights Law, 18 U.S.C. Section 245(b)(2), which affirmed individuals' rights to engage in six types of federally-protected activities, such as applying for jobs, using any facility of interstate commerce, attending school, participating in public activities, patronizing a public facility, voting, or serving as a juror in a state court. This law stated that anyone who intimidated, interfered with, or injured another person who engaged in any of the six federally-protected activities, or attempted to do so, because of the other person's color, race, national origin or religion was defined as a hate-crime offender.

Twenty-five years later, in 1994, one of the largest crime bills in the United States history, the Violent Crime Control and Law Enforcement Act, was sent to the United States Sentencing Commission. This Act required greater penalties for violent crimes such as hate crimes, which were based on the actual or perceived color, religion, race, national origin, ethnicity or gender of the victims. The Act was then passed and enacted in 28 U.S.C. Section 994 note Section 280003 by the United States Sentencing Commission. Unfortunately, this Act did not eliminate the restriction stated in the 1964 Federal Civil Rights Law, which required that the victims must be engaged in a federally-protected activity when such violations occur (this Act only increased the penalties for hate crimes. Three years after the enactment of the Violent Crime Control and Law Enforcement Act, in 1998, the Matthew Shepard incident occurred. ${ }^{17}$ On October 28th, 2009, eleven years after Shepard's death, President Obama signed the Matthew Shepard and James Byrd, Jr. Hate Crimes Prevention Act which expanded the existing U.S. hate crime laws to include crimes motivated by a victim's actual or perceived gender, sexual orientation, gender identity, or disability. This Act dropped the prerequisites in the 1964 Federal Civil Right Law and the 1995 Violent Crime Control and Law Enforcement Act, both of which required victims to be engaged in one of the six federally-protected activities. ${ }^{18}$

${ }^{17}$ On October 7th, 1998, two men pretending to be gay abducted Matthew Shepard, a gay college student, tied him to a fence, beat him with a pistol, and left him for dead. He was found almost eighteen hours after the attack and he died a few days later. Sam Sheppard was at the center of the highest profile crime in Ohio history. S. Duimovich: A critique of the Hate Crimes prevention act regarding its protection of gays and lesbians (and now a private right could fix). "Southern California Review of Law and Social Justice" 2014, no. 23 (2), pp. 297-298; J.L. ENTIN: Being the Government means (almost) never having to say you're sorry: The Sam Sheppard case and the meaning of wrongful imprisonment. "Akron Law Review" 2005, no. 38, p. 139; W. Cheng, W. ICKes, J.B. KenworthY: The phenomenon of hate crimes in the United States. "Journal of Applied Social Psychology" 2013, no. 43 (4), p. 761. See more: J.L. EnTIN, Being..., pp. 139 ff.

${ }^{18}$ W. Cheng, W. ICKes, J.B. Kenworthy: The phenomenon..., p. 762. 
In the United States, the prevention, investigation, and also prosecution of crimes against persons or property whether or not motivated by hate is primarily the responsibility of local authorities. The federal role is only limited but nonetheless crucial, with federal authorities serving most often as a backstop when local efforts to address bias-crimes issues fail. Local police are the front line in preventing and also in investigating hate crimes. The mandate of most police forces is similar to that contained in the New York City Charter: "The police department and force shall have the power and it shall be their duty to preserve the public peace, detect and arrest offenders, prevent crime, suppress riots, mobs and insurrections [...], protect the rights of persons and property [...] and for these purposes to arrest all persons guilty of violating any law or ordinance [...]." County prosecutors are primarily responsible for prosecuting crimes covered by state legislation, like hate crimes. It is worth notice that in some counties, county officials have created specialized hate-crime prosecution units staffed by prosecutors who receive specialized hate crime prosecution training. Hate crimes also often fall within the mandate of not just local but also state civil rights agencies. In recent years, some cities and states have created agencies that specifically address hate crime. One of them is the California Civil Rights Commission on Hate Crimes that was created in 1998 to advise California's attorney general on methods to improve hate-crime prevention, and appreciation for diversity and tolerance, law enforcement training, and the monitoring and suppression of organized extremist groups. In turn, the Michigan Alliance Against Hate Crimes (MIAAHC) is a statewide coalition of federal, state, and local law enforcement agencies, civil rights organizations, and community-based groups who meet periodically to exchange ideas on ensuring that responses to hate crimes are complete and effective. What is important, a few entities have been created with a specific focus on issues affecting the Arab and Muslim communities. The Chicago mayor's office has an Advisory Council on Arab Affairs which provides guidance and direction on issues affecting the Arab community in Chicago, including hate crimes.

It is worth mentioning that federal officials complement and supplement the efforts of state and local agencies to prevent, investigate, monitor and prosecute hate crimes. The Civil Rights Division of the U.S. Department of Justice is charged with enforcing and prosecuting federal hate-crime laws. The Community Relations Service (CRS), an organization within the U.S. Department of Justice, established by the 1964 Civil Rights Act, is one of many federal agencies that assist in addressing bias-motivated violence, assisting communities in addressing intergroup disputes. CRS mediators, working with police officials and civil rights organizations, have often acted to defuse community tensions that might 
otherwise escalate into ethnic or racial violence. Also established by the 1964 Civil Rights Act, the U.S. Commission on Civil Rights (UCCR) holds hearings and briefings on race relations and hate-related violence. UCCR presents its findings on civil rights issues, such as hate violence, in reports submitted to the U.S. Congress and relevant federal agencies. ${ }^{19}$

The Federal Bureau of Investigation (FBI) is the primary domestic law enforcement agency of the federal government. It conducts investigations into crimes covered by federal hate-crimes legislation and can also assist local police with hate-crime investigations. ${ }^{20}$

The Bureau of Justice Statistics (BJS) is an office within the U.S. Department of Justice. It collects, analyzes, publishes, and disseminates information on crime, including hate crimes, victims of crime, criminal offenders, and the operation of justice systems at all levels of government. It is responsible for publishing an annual nationwide hate-crimes report that provides the most comprehensive national statistical overview of hate crimes.

The Bureau of Justice Assistance (BJA) is another arm of the Justice Department that provides grants to support local police and government agency efforts to build safe communities. ${ }^{21}$

There are no doubts, however, that hate crimes are a uniquely important and socially devastating kind of crime that warrant enhanced public attention and action. What distinguishes a hate crime from others is not the act itself, murder or assault, but the racial, gender, ethnic, religious or sexual orientation animus that propels its commission. Unfortunately, despite much legislative progress, hate crimes still persist. ${ }^{22}$

${ }^{19}$ It is worth mentioning that UCCR has branch offices in each of the fifty states in the United States. See more: Human Rights Watch: USA: "We Are Not the Enemy": Hate Crimes Against Arabs, Muslims, and Those Perceived to be Arab or Muslim after September 11. 14 November 2002, G1406, available at: https://www.refworld.org/docid/45db101e2.html [accessed 4 April 2020].

20 The results of the Federal Bureau of Investigation (FBI) investigations are used by the Civil Rights Division and the United States attorneys to initiate federal hate-crime prosecution. The FBI in conjunction with CRS, also trains local law enforcement agencies in federal standards of data collection contained in the HCSA and publishes hate-crime data collection guidelines for local police agencies. Ibidem.

${ }^{21}$ Human Rights Watch: USA: “We Are Not the Enemy": Hate Crimes Against Arabs, Muslims, and Those Perceived to be Arab or Muslim after September 11. November 14th, 2002, G1406, available at: https://www.refworld.org/docid/45db101e2.html [accessed 4 April 2020].

22 W. Cheng, W. ICKes, J. B. Kenworthy: The phenomenon..., p. 762; See more: Human Rights Watch: USA: "We Are Not the Enemy": Hate Crimes Against Arabs, Muslims, and Those Perceived to be Arab or Muslim after September 11. 14 November 2002, G1406, available at: https://www.refworld.org/docid/45db101e2.html [accessed 4 April 2020]. 
Case histories indicate that hate crimes are vile offenses. What is more, the problem of hate crimes has worsened in recent years. ${ }^{23}$

For more than a decade the federal government has collected and then published data on hate crimes. Since the mid-1990s the number of hate crimes reported has been remarkably consistent: Each year in the United States there are about 4,600 reported incidents of racial hate crimes and 1,400 reported incidents of religious hate crime. ${ }^{24}$

Table 1. Offenses according to the FBI statistics by bias motivation (category during the last years).

\begin{tabular}{|l|r|r|r|r|c|}
\hline Category $^{\text {a) }}$ & $\mathbf{2 0 1 4}$ & $\mathbf{2 0 1 5}$ & $\mathbf{2 0 1 6}$ & $\mathbf{2 0 1 7}$ & $\mathbf{2 0 1 8}$ \\
\hline Race $^{\mathrm{b})}$ & 3081 & 4029 & 4229 & 4832 & 4954 \\
\hline Religion $^{\mathrm{c})}$ & 1092 & 1354 & 1538 & 1679 & 1550 \\
\hline Sexual orientation $^{\mathrm{d})}$ & 1178 & 1219 & 1218 & 1303 & 1404 \\
\hline Disability $^{\mathrm{e})}$ & 95 & 88 & 76 & 128 & 177 \\
\hline
\end{tabular}

a) It is worth mentioning that there are also other kinds of hate crimes like: Gender (Anti-Male, Anti-Female), Gender identity (Anti-Transgender, Anti-Gender Non-Conforming).

b) This category includes: Anti-White, Anti-Black or African American, Anti-American Indian or Alaska Native, Anti-Asian, Anti-Native Hawaiian or Other Pacific Islander, Anti-Multiple Races Group, Anti-Arab, Anti-Hispanic or Latino, Anti-Other Race/Ethnicity/Ancestry.

c) This category includes Anti-Jewish, Anti-Catholic, Anti-Protestant, Anti-Islamic (Muslim), Anti-Other Religion, Anti-Multiple Religions Group, Anti-Mormon, Anti-Jehovah's Witness, Anti-Eastern Orthodox (Russian, Greek, Other), Anti-Other Christian, Anti-Buddhist, Anti-Hindu, Anti-Sikh, Anti-Atheism/Agnosticism/etc.

d) This category includes Anti-Gay (Male), Anti-Lesbian, Anti-Lesbian, Gay, Bisexual, or Transgender (Mixed Group), Anti-Heterosexual, Anti-Bisexual.

e) This category includes Anti-Physical, Anti-Mental.

Source: FBI Hate Crime Statistics: 2014, 2015, 2016, 2017, 2018, available at: https://ucr.fbi. gov/hate-crime [accessed 4 April 2020].

One point that stands out is every instance of bias-motivated behavior must be recorded and dealt with. Very often incidents which on the surface appear to be isolated, frequently are not. Such incidents are oftentimes the culmination of a lengthy history of hate, motivated by aggression and harassment between the parties to the incident. Understanding of the extent of the problem of hate-motivated behavior is necessary to develop

${ }^{23}$ L.R. Gale, W. Carrington Heath, R.W. Ressler: An economic analysis of hate crime, available at: https://core.ac.uk/download/pdf/6875029.pdf [accessed 17 April 2020].

${ }^{24}$ In the United States Hate Crime Statistics Tell a Story of Their Own. In: Global View Points. Hate Crimes..., p. 51. 
policies likely to effectively minimize such behavior. Accurate figures are a necessary tool for measuring the effectiveness of programs. ${ }^{25}$

\section{Racist $^{26}$ and religious hate crimes}

Race, ethnicity or national origin-based discrimination are types of hate that unfairly and systemically assign value based on race, ethnicity, or national origin and affect the daily realities of many communities. ${ }^{27}$

Mainstream social scientists have often examined not just the paired ideas of racial and religious prejudice discrimination. A common exemplification has been the one of individual bigots acting out racial attitudes in discriminatory ways. In recent decades, some critical analysts and researchers have argued for a different emphasis in looking at racial prejudice and discrimination; they stress not just the systemic but also an institutional racism that undergirds individual acts of discrimination. In its origin, this institutional racism viewpoint mostly stems from a long line of African American activists and scholars, going back centuries. Thinkeractivists long ago put white society and its societal institutions at the center of critical analysis of white racism. ${ }^{28}$ The civil rights movement in the 1960s brought a renewed emphasis among black intellectuals and activists on the institutional contexts of individual discrimination. While in recent years numerous mainstream analysts have rejected a critical institutionalracism perspective, it remains a very important approach to understanding the depths of the United States system of discrimination and racial hosti-

25 J. Wieland: Peer-on-Peer Hate Crime and Hate Motivated Incidents Involving Children in California's Public Schools: Contemporary Issues in Prevalence, Response and Prevention, 11 U.C. "Davis Journal of Juvenile Law and Policy" 2007, pp. 268-269.

${ }_{26}$ The term "race" is quite controversial in legal discourse, and nowadays is considered to be virtually unacceptable in academic discussions. Nevertheless, this rejection of the term "racism" does not negate the existence of the phenomenon known as racism and racist motivation of crimes in the narrowest sense of the term. Racists usually understand "race" in accordance with outmoded views on this subject, which were dominant in society one or even two generations earlier. The characteristic of "race" as encountered in the laws of different countries is defined differently in each instance. A. VerKHOVsKY: Criminal Law on Hate Crime, Incitement to Hatred and Hate Speech in OSCE Participating States, available at: https://www.sova-center.ru/files/books/osce-laws-eng-16.pdf [accessed 4 April 2020].

27 Race, Ethnicity and National Origin-Based Discrimination in Social Media and Hate Crimes Across 100 U.S. Cities. Paper presented at 13th International Conference on Web and Social Media, ICWSM 2019, Munich, Germany, p. 417.

${ }^{28}$ Thinker-activists include Frederick Douglass and W.E.B. Du Bois. See more: J.R. Feagin: Racist America: Roots, Current Realities, and Future Reparations. New York 2000, pp. 143-144. 
lity. Today, Americans of color generally experience discrimination both from the actions of individual whites in one social arena and from the everyday, recurring actions of the white populace across many of life's arenas; actions backed by a multifaceted and powerful system of institutionalized white power and privilege. Over recent decades the international confrontation of all racial and ethnic discrimination unfortunately has deescalated. According to the United Nations International Convention on the Elimination of All Forms of Racial Discrimination, that was implemented in the year 1969, discrimination is any exclusion, distinction, restriction or preference based on race, color, descent or national or ethnic origin which has the purpose or effect of nullifying or impairing the recognition, enjoyment or exercise, on an equal footing, of human rights and fundamental freedoms. This broad view accentuates distinctions on the basis of racial grouping and institutionalized restrictions, preferences, and exclusion aimed at impairing human rights. What is more, it also underscores the costs associated with being the target of discrimination. ${ }^{29}$

This kind of violence excites an extraordinary level of public condemnation, arousing passions that exceed the reaction to other forms of largescale violence or human tragedy. ${ }^{30}$

The reasons for attacks against individual and groups stems from their adherence to a particular faith, or their openness about their beliefs. Hatemongers, blinded by religious fervor and fanaticism, hurt others whom they view as a danger to their own beliefs and to society at large. Regarding both the victim and the perpetrator of religious hate crimes, one's faith is something to be taken seriously, sometimes to the extreme. ${ }^{31}$ The motive of hatred is usually ideological in nature. Even if a hate crime is committed by a person who is not involved in any racist or similar group, such a person still harbors some notion of inequality - if this were not the case, the motive would be different and the crime would not be a hate crime. Determination of the perpetrator's ideological grounds is usually of no interest to lawmakers. ${ }^{32}$

29 The U.S. government did not ratify this convention until 1994. What is more, since the early 2000s the United Nations has had two important world conferences dealing with international racism, including issues of reparations for U.S. slavery and colonialism. Top U.S. officials have declined to participate in either conference. J.R. FEAGIN: Racist America..., pp. 144-145.

30 F.M. Lawrence: The Hate Crimes/Hate Speech Paradox: Punishing Bias Crimes and Protecting Racist Speech. "Notre Dame Law Review" 1993, no. 68; GWU Legal Studies Research Paper No. 342, p. 673.

31 M.B. BARKa: Religion..., pp. $107 \mathrm{ff}$.

32 A. Verkhovsky: Criminal Law on Hate Crime, Incitement to Hatred and Hate Speech in OSCE Participating States, available at: https://www.sova-center.ru/files/books/osce-laws -eng-16.pdf [accessed 4 April 2020]. 


\subsection{Racist hate crimes}

Example: One of the more fear-inducing racist hate crimes took place in Indiana state where a man has been charged with a hate crime after he burnt a cross and displayed a swastika in his garden, in an attempt to intimidate his African American neighbor.

Another example: The 50-year-old became angry on June 18th when his unnamed neighbor hired a crew to remove a tree from his own property in Lawrence, Indiana. In order to intimidate his neighbor, Mr. Hoehn burnt a cross above the fence line between the two properties, displayed a swastika and hung up a large sign that included anti-black racial slurs. ${ }^{33}$

\subsection{Hate crimes committed for reasons of religion}

Case study 1: Daniel Romano was assaulted at the beginning of 2000 while walking down the street in New York in a black trench coat and with an inverted cross around his neck. Two teenagers attacked him. They pulled up beside him in a blue sedan and beat him with an ice scraper and a metal pipe. The two teenagers were determined to harm him because they disagreed with Satanism, which they considered to be a physically violent and sacrificial religion. When asked by the police, the victim denied that his religion was brutal. Regardless of the social image and teachings of his faith, Romano fell victim to a hate crime because he overtly expressed his religious beliefs.

The aggressor views his victims' religion as contrary to what he himself believes to be "good and right." Such an attitude is revealing of a dualistic black-and-white worldview.

Seen through the eyes of aggressor, the world seems to be a battlefield where the opposing armies of "good" and "evil" are engaged in a life-anddeath struggle. A closer look at this case indicates how any believer, regardless of his or her creed, can unfortunately be a victim of a religious hate crime. There is no one "safe" or "hate crime-free" religion. A crime that is prompted by faith also involves the further attack against a person's system of beliefs: “[...] a religious hate crime perpetrator does not just attack a person. This person attacks a religion, a way of life, and even a whole community. With the argument mentioned above, it may be said

${ }^{33}$ Man charged with burning cross and displaying swastika to intimidate neighbor, available at: https://www.independent.co.uk/news/world/americas/man-charged-withburning-cross-to-intimate-neighbour-a9665236.html [accessed 23 August 2020]. 
that hate crimes work like terrorism: although there may be only one victim, hate crimes target and terrorize an entire community. One example of this is when a Jewish person is attacked because he or she is a Jew, a threatening message is sent to the entire community: "If we find Jews, we will attack them." It is this terror which is actually punished by anti-hate crime laws. What is important, a religious hate crime may well triggerdangerous cyclical acts of violence among groups and/or individuals with differing beliefs.

Unlike disability hate crimes which are single-bias incidents, in most cases offenses based on bias against religion are multiple bias-crimes, given that religion and ethnicity, which may include both race and nationality, tend to overlap. Just as Jewry and Judaism are inseparably linked, someone of Middle Eastern origin or descent, or even a South Asian is almost systematically regarded as an Arab or a Muslim.

While most perpetrators of religious hate crimes operate on their own, without being directly guided by the members of any organized group, some are very zealous individuals associated with cults, far-right hate groups, or radical fundamentalist movements. Their worldview rests on religious foundations.

Case study 2: The Westboro Baptist Church (WBC) that was established in Topeka, Kansas in 1955, and led by Pastor Fred Phelps, is more than just a religious faith group. It is an anti-gay activist organization which, outside the parish, enjoys the support of a wider gay-hating community. Its members believe that homosexuality is sinful and that God hates and condemns all gay persons. Significantly, its internet website is called "God Hates Fags". The hate crimes committed by the WBC mostly consist of harassment and assault, especially during demonstrations riots. One such picket outside the funeral of a slain gay University of Wisconsin student shocked the entire United States. It gained worldwide publicity in October 1998 (already mentioned Matthew W. Shepard case).

As we can see, one may infer that religious fanaticism is more likely to spawn bigotry and hate-crime activity. For Aryan Nations, the Westboro Baptist Church (WBC) religion is the cornerstone upon which the entire movement, the far right, is based. It holds a traditional view of marriage and family, and considers homosexuality as sinful. When demonstrating during Matthew W. Shepard's funeral, the WBC made known its disapproval of Shepard's sexuality and lifestyle. In this respect, it is worth noticing that when invective utterances against gays appear in right-wing literature, they are frequently supported by some arguments: homosexuality is seen as morally and biblically wrong and queer-bashers assert that gays have gone too far in their push for special rights. In many cases, anti-gay 
violence is probably also engendered by offenders' perceptions that gays have violated gender roles. ${ }^{34}$

Considering the wide variety of religions which both fall victim to and commit crime in America, there can be no "hate-crime-free" religion (if an individual carries the teachings and faith beliefs of his or her religion to the extreme, he or she may become a perpetrator of a hate crime. Of course this does not mean that all fundamentalists and religious radicals systematically engage in criminal activities).

Moving to the issue of racist crimes, it is worth notice that there are so many types of them. One category is hate crimes against black Americans. ${ }^{35}$

Unfortunately, white attacks and other hate crimes against black Americans and numerous other Americans of color are still part of the U.S. landscape. The Federal Bureau of Investigation (FBI) report from 2012 on single-bias hate crimes noted there had been 3,645 victims of racially-motivated crimes in the previous year. ${ }^{36}$ Some hate incidents have ranged from aggressive verbal harassment of pedestrians and coworkers, the placement of threatening nooses on doors and the scrawling of racist graffiti on homes and cars, to more violent attacks including killings. Periodically, some whites in the growing number of white-supremacist and racial-nationalist groups have threatened large-scale violence against Americans of color. In the United States of America there are many extreme white-nationalist groups like the Ku Klux Klan groups and a variety of neo-Nazi groups and armed white militias. Nationally, in 2013, the Southern Poverty Law Center counted more than 1,000 known hate groups operating actively across the U.S., a great many of them Klan and other white supremacists, neo-Nazis, racist skinheads, and border vigilante organizations, with at least 300,000 whites as active or passive supporters. Sometimes members of these white-nationalist groups, as well as thousands of others who read their literature, engage in racially motivated crimes. After the 2008 presidential election there were at least 200 incidents of hate-based vandalism and threats of violence against the then President-elect Obama, exceeding those directed toward any previous U.S. president. Unfortunately, death

34 This is the opinion of Phyllis B. Gerstenfeld. M.B. BARKa: Religion..., pp. $107 \mathrm{ff}$.

35 It is worth mentioning that although African Americans are still major targets, according to the SPLC many of the hate-based crimes haves involved immigrants of color, especially those from Latin America. The number of racist hate groups (e.g. Klan, neo-Nazi) groups, has also grown dramatically in recent years. J.R. FEAGIN: Racist America..., p. 163.

${ }^{36}$ It is worth mentioning that this report states that "victim may refer to a person, business, institution," but most are individuals; these numbers are serious underestimates because most of the more than 17,000 police jurisdictions did not report their hate crimes, reported for only part of a year, or reported zero hate crimes. Ibidem, p. 163. 
threats have continued throughout Obama's presidency, many of them likely being racially motivated. ${ }^{37}$

The number of hate crimes in the United States seems unlikely to decline in part because of America's racial, ethnic and religious diversity which, according to the U.S. Census Bureau has increased more dramatically over the past few years than at any other time in history. Today, nearly one in every four Americans claims African or Native American ancestry, and ethnic enclaves exist even in remote rural communities. While this new diversity enriches American culture, it unfortunately also complicates race relations. ${ }^{38}$

A climate of tolerance and inclusion, beginning in the late 1960s, has created many challenges to the status quo and thus more opportunities for outsiders to be victimized. Far from negligible, the backlash provoked by the September 11th, 2001 terrorist attacks has considerably contributed to the rise in hate crimes. ${ }^{39}$

\section{Sexual orientation-based hate crimes}

The prevalence of criminal victimization that is based on an individual's perceived sexual orientation, commonly referred to as anti-gay hate crimes or also bias-crimes, has been a major concern for the LGBTQ community dating back to the 1980s. During the 1980s, there was a dramatic increase in anti-gay hate crimes reported to gay and lesbian community organizations. Hate-motivated violence exists across a spectrum of escalation whereby any single incident may involve various types of violence. This is especially true of sexual orientation-based hate crimes. Not only verbal attacks but also workplace discrimination, intimate partner abuse, sexual assault, and beatings can all be motivated by hatred harbored against an LGBTQ identity. One of the studies from the Harvard School of Public Health asserts that people identifying as gay, lesbian, bisexual, or having had a same-sex partner are 1.5 to 2 times as likely to experience violence within the general population. A consistently elevated rate of hate-violence incidents during Pride months, as well as in October 2009, around the time of federal hate-crimes law passage, seems to reflect a correlation between increased visibility and increased vulnerability and targeting of LGBTQ people. Such compelling evidence indicates the profound need for

37 Ibidem, p. 164.

${ }^{38}$ N. Ghant: The Rise of Islamophobia in the United States: Patterns, Perpetrators, and Reactions. “American International Journal of Contemporary Research" 2018, no. 4 (8), p. 5.

39 J.R. Feagin: Racist America..., p. 164. 
both mainstream and LGBTQ-specific service providers to understand the social conditions and discrimination that engender such violence. ${ }^{40}$

Some surveys indicate that more than $50 \%$ of homosexuals in the United States have been the victims of sexual orientation- based hate crimes, including attacks. A Department of Justice report noted that they are probably the most frequent victims of hate crimes. ${ }^{41}$

Hate crime in the area of LGBTQ is usually defined as homophobic or transphobic hate crime, which provides a framework for lesbians, gay men and trans men/women. However, little space is provided to conceptualize the hate experiences of individuals who do not fit neatly into these concepts, such as asexuals, bisexuals, pansexuals and non-binary people. ${ }^{42}$ Hate crimes toward persons who are lesbian, gay, bisexual, or transgendered look virtually the same as hate crimes toward persons based on the color of their skin, ethnic background, or religion. ${ }^{43}$ Trans people are particularly susceptible to hate crimes, not just in terms of prevalence but also in frequency. ${ }^{44}$ Lesbian, gay and bisexual men and women are unfortunately frequent targets of vicious hate crimes. In 2001, the Federal Bureau of Investigation (FBI) reported that sexual orientation-based hate crimes are the third most commonly reported hate crimes. These kinds of crimes have remained constant even as the incidence of violent crime in general has fallen dramatically, although sexual orientation- based hate crimes are now widely recognized as a serious problem in the United States. LGBTQ people are commonly targeted in part because systemic

${ }^{40}$ It is worth notice that this kind of violence is not just an epidemic confined to the United States. This pandemic spans the globe, cutting across continents, cultures, and languages. J.D. KIDD, T.M. Witten: Transgender and Transsexual Identities: The Next Strange Fruit-Hate Crimes, Violence and Genocide against the Global Trans Communities. "Journal of Hate Studies" 2007, no. 6 (1), p. 40; S. CAMPBELL: The Prevalence of Hate Crimes Motivated by Sexual Orientation in Florida after the U.S. Supreme Court Legalization of SameSex Marriages. Nova Southeastern University, A Dissertation Presented to the Department of Justice and Human Services of Nova Southeastern University in Fulfillment of the Requirement for the Degree of Doctor of Philosophy, 2019, pp. 36-37.

${ }^{41}$ Hate Crimes Violence. Hearing before the Committee on the Judiciary House of Representatives. One Hundred Sixth Congress. First Session, August 4th, 1999, Serial No 74, Washington 2000, p. 51.

${ }^{42}$ LGBT Hate Crime: Promoting a Queer Agenda for Hate Crime Scholarship. "Journal of Hate Studies" 2019, no. 15 (1) p. 39.

${ }^{43}$ E.P. Cramer: Hate Crime Laws and Sexual Orientation. "The Journal of Sociology \& Social Welfare" 1999, no. 26 (3), pp. 20-21.

${ }_{44}$ M.A. Walters, J. Paterson, R. Brown, L. McDonnell: Hate Crimes Against Trans People: Assessing Emotions, Behaviors, and Attitudes Toward Criminal Justice Agencies. "Journal of Interpersonal Violence", available at: http://sro.sussex.ac.uk/id/eprint/67633/4/ Hate\%20Crimes\%20Against\%20Trans\%20People\%20-\%20final\%20version\%20for\%20 open\%20access.pdf [accessed 23 August 2020]. 
discrimination has rendered them unwilling or unable to report violence or led them to believe that if they do make a report they may not be taken seriously by law enforcement. These fears of revictimization by law enforcement are not unfounded. It is difficult to know the true prevalence of sexual orientation-based hate crimes. In spite of the fact that anti-LGBTQ hate-crime incidents take a variety of forms, they tend to share common characteristics. Offenders, through their actions, intend to send a message that their acts of brutality are justified and deserved because LGBTQ people do not have the right to live free from violence, or in the most extreme cases, do not have the right to live at all. In the mind of the hate-violence offender, actual or perceived LGBTQ identity means that a person exists outside of acceptable social behavioral norms, and thus, the offender may use harassment, attacks, sexual assault or even murder in order to silence that LGBTQ identity. A common impact of these acts is that they send a message of fear to the individuals targeted and to the communities to which the individual belongs. An additional characteristic of hate-violence incidents is overkill, where in the course of physical violence offenders use extreme brutality. Offenders may attack their targets in close contact and with extreme force. The targeting of specific body parts is very often an association of those parts with the hated identity of the victim. Anti-LGBTQ hate violence frequently involves overkill, as a way of deeply personalizing an attack, brutally "othering" a person of the targeted identity.

Sexual orientation-based hate crimes are individual expressions of the discriminatory social, legal, political and economic forces that comprise heteronormativity; the practices and institutions "that legitimize and privilege heterosexuality and heterosexual relationships as fundamental and 'natural' within society." 45

This kind of hate violence also has profound consequences, not only for transgender people, but for society as a whole. Hate violence also decreases the likelihood that transgender people will obtain health services after violent incidents, as they fear revictimization by hospital staff or law enforcement. A negative cycle is established in which victims of violence endure their pain in silence, putting them at risk for mental illnesses as well as making them even more likely to experience a second victimization during their lifetime. The large number of such crimes warrants the inclusion of hate crimes as part of the hate crimes statutes throughout the United States and the rest of the world. What is more, accurate hate-crime statistics should be collected for sexual orientation-based hate crimes. These findings point to the need for further research into the causes and

${ }^{45}$ Ibidem, pp. 34-36, 37-38. 
consequences of anti-transgender hate violence, as well as a need for a reexamination of how support services can be made more accessible to victims of sexual orientation-based hate crimes. ${ }^{46}$

Media-grabbing cases that drew attention to hate-motivated crimes against gays and lesbians include the 1998 murder of a gay Wyoming student. The murder, which garnered extensive media coverage, eventually led to the enactment of the Hate Crimes Prevention Act (HCPA), which expanded the federal hate crime law to include sexual orientation-based hate crimes. This case (which is called Shepard's case) brought much needed attention to hate crimes. While detestable, Shepard's case was not the only crime seemingly motivated by ill will toward a minority member. ${ }^{47}$

In 2009, Congress enacted the Hate Crimes Prevention Act which included sexual orientation as a protected class. That marks the first major federal protection for victims of crimes or acts of bias due to an individual's sexual orientation. ${ }^{48}$

Though different from hate-crime legislation, the federal code contains other protections against certain bias-motivated acts. Unfortunately many of them are not available to gays and lesbians. ${ }^{49}$ In 2013 Congress allowed victims of same-sex domestic abuse the same protections and resources heterosexual victims receive under the Violence Against Women Act (it means that Congress did expand one non-hate crime discrimination protection to gays and lesbians). With the exception of the new antidiscrimination rules in VAWA and the addition of sexual orientation as a protected class under the HCPA, lesbians and gays have little federal protection. There is no doubt that the enactment of the HCPA was a pivotal moment for the advancement of LGBTQ rights. Unfortunately, it did little to shelter lesbians and gays from hate crimes because of its limited applicability and usage. Lesbians and gays fair better on the state level: thirty states have hate crime laws that cover crimes based on sexual orientation. At the forefront, since many state laws do not have protections that are based on sexual orientation, new federal laws would be the best option to address this lack of protection since they would apply nationwide.

46 J.D. KidD, T.M. WitTEN: Transgender..., p. 46.

${ }^{47}$ Sam Sheppard was at the center of the highest profile crime in Ohio history. S. Duimovich: A critique..., pp. 297-298; J.L. Entin: Being..., p. 139.

48 S. Duimovich: A Critique..., p. 295.

${ }^{49}$ One of them is the Title VII that protects employees from discriminatory acts based on their race, color, religion, sex, or national origin. In certain contexts, Congress has also prohibited employers from discriminating on the basis of age, disability, or genetics. Unfortunately, none of these protections include sexual orientation as a protected class. S. Duimovich: A Critique..., p. 304. 
Every year thousands of hate crimes are committed, representing only 35 percent of the hate crimes that actually occur. With hate crime statistics so high (especially against lesbian and gay individuals) the HCPA seems to be ineffective (the HCPA applies only to criminal actions). Enforcement of the solely criminal HCPA suffers from not just prosecutorial discretion and high burden of proof but also jury bias.

The other issue that is worth notice is the prosecutorial discretion. Prosecutors have full discretion to decide when to attach hate-crime enhancements to indictments because hate-crime statutes only apply to criminal acts. ${ }^{50}$ Without judicial compulsion, short of an executive order or a legislative act, victims are without recourse under the HCPA if prosecutors decline to investigate or prosecute hate crimes. Prosecutors are either elected or appointed, and their decision-making can be driven by future ambition and public approval. Evidence suggests that many federal and state prosecutors tend not to utilize hate crime statutes if prosecutors choose not to investigate or prosecute hate-crimes.

The other problem of the HCPA is the high burden of proof required to validate a criminal conviction. In criminal cases, all alleged crimes must be proved beyond a reasonable doubt. Since the HCPA is a criminal statute, any conviction under the statute must meet be the reasonable doubt standard. Unfortunately this standard is especially hard to meet when prosecuting a hate crime because the prosecution needs to prove beyond a reasonable doubt that the defendant targeted the victim because of an actual or perceived bias. If, however, the HCPA has a private right-of-action, a victim could sue the perpetrator in a civil court where the burden of proof is a preponderance of the evidence. Because it is outside the criminal context, the defendant would not face jail time, but the plaintiff would only have to prove enough facts to convince the jury that it is more likely than not that the defendant was motivated by a bias in targeting the victim.

${ }^{50}$ For example, in Inmates of Attica Correctional Facility v. Rockefeller, the Second Circuit Court of Appeals held that both law and tradition restrict courts from compelling prosecuting agencies to initiate investigations or influencing prosecutors' discretion to bring charges against an individual; thus, courts cannot review a prosecutor's decision to prosecute or refrain from prosecuting a hate-crime enhancement. The court held that even when "serious questions are raised as to the protection of civil rights and physical security of a definable class of victims of crime and as to the fair administration of the criminal justice system" prosecutors should maintain their discretion free from judicial intervention. The Supreme Court has also held that "a citizen lacks standing to contest the policies of a prosecuting authority when he himself is neither prosecuted nor threatened with prosecution," meaning the victim of a crime cannot challenge a prosecutor's decision. S. Duimovich: A Critique..., pp. 304-306. 
Gays and lesbians also face other hardships and have little protection provided by the government. The general lack of protection by the federal and state government contributes to their plight. It is worth notice that the HCPA's effectiveness is stymied by prosecutorial inaction; a high criminal burden of proof, and potential jury bias. Courts have established that the HCPA does not provide a private right-of-action (in spite of the fact that a private right-of-action would address, at least in part, each of these concerns). It is not just hate crime laws that create obstacles for minorities to use legal means to alleviate acts of bias against them: selectivity of current laws and the administrative remedy requirements hamper other anti-discrimination efforts. It is worth notice that some of the existing anti-discrimination statutes selectively protect certain minority groups.

A private right-of-action is the next issue that is worth scrutinizing. There are many strengths of adding a private right-of-action, including mitigating the lack of enforcement problem, lowering the burden of proof, allowing for compensatory relief, side-stepping the administrative exhaustion requirement, shifting some of the financial burden away from the federal government and promoting equality throughout the states. First of all, prosecutors would no longer have the sole discretion with regard to bringing a case. Moreover, private right of action would allow victims to circumvent the political pressure of the prosecuting government agency and bring suits privately. Secondly, a private right-of-action would lower the burden of proof. Hate crimes warrant this lower burden of proof because juries evaluating hate crimes must wrestle with the defendant's motivation and reasons behind the targeting of the victim, which involves inquiries into intent (an element that does not lend itself as easily to concrete facts as other elements). Thirdly, a private right-of-action would allow hate-crime victims to recover monetary damages. Of course, compensation should also account for the additional suffering that hate-crime victims may experience, and a private right-of-action would allow this. Moreover, a private right-of-action allows for the public acknowledgement that a hate crime occurred, which may bring some closure to a victim. Fourthly, a private right of action in the hate-crimes context could free victims of the administrative remedy exhaustion requirements. Claims would not be unduly delayed by months or years while an agency processed them, because a private right would not or should not be exempt from the administrative exhaustion requirements. The private right would obtain a judgment more quickly. Fifthly, a private right-of-action would shift some of the financial burden from the federal government to the private sector. The HCPA allows federal and local prosecutors to use federal money for investigating and prosecuting hate crimes. It should be noted 
that while this would not change with the addition of a private right-ofaction, allowing a private right-of-action could help prosecutors save time and money by allowing private attorneys to do some or all of the work. Investigations performed by private attorneys would not be federally funded and the privately-obtained information could be shared with the victim's consent, so prosecutors could bring more cases with the saved time and money. A private right-of-action would also promote equality throughout the states and would help to deter sexual orientation-based hate crimes.

In conclusion, lesbians and gays are one of the most discriminated against groups, however, they have some of the fewest legal protections. Adding a private right-of-action to the HCPA is the mean to deter the worst violent acts against minorities. Even when prosecutors refuse to charge perpetrators, a private right would allow civil cases to be brought. There are so many advantages of the right to privacy (that was mentioned above) such as: providing a lower burden of proof to combat juror bias, shifting some of the financial burden of prosecution, labeling more perpetrators as hate-crime offenders, compensating victims, removing some administrative burden and allowing for a more equitable and just remedy. The United States of America could utilize a private right-of-action for hate-crime violations to continue to encourage tolerance, equality and security. The important thing is that the private right can protect victims, punish perpetrators and preserve the constitutional rights of all citizens. ${ }^{51}$

\section{Disability-based hate crimes}

Individuals with disabilities are much more susceptible to victimization due to situational and personal factors which foster dependence and vulnerability. Studies have shown that unfortunately the chance of being physically assaulted can be 4 to 10 times greater for individuals with developmental disabilities. The data indicated that the risk of an individual with a disability being the victim of a hate crime was relatively rare. On the other hand, the risk of being the victim of simple assault was proportionately greater than that for any of the other protected groups.

When Congress re-authorized the Hate-Crime Statistics Act in 1994 the Federal Bureau of Investigation (FBI's Uniform Crimes Reporting Section) began keeping data based on crimes against persons, property,

51 S. Duimovich: A Critique..., pp. 306-308, 312, 316-320, 326-327. 
and society, as well as multiple offense crimes. Additionally, disability was added to the list of protected categories. ${ }^{52}$

Disability hate crime is defined as "any criminal offense which is perceived, by the victim or any other person, to be motivated by a hostility or prejudice based on a person's disability or perceived disability." ${ }^{33}$ It is a category of crime that arises from the hostility of the perpetrator towards the disability, perceived disability of the victim, or because of their perceived connection to disability. This kind of crime represents Disablism carried through into criminal acts against the person. Unfortunately, when the nature of a person's disability makes it easier for the offender to commit a particular offense, police and prosecutors often focus on the victim being "vulnerable" or an "easy target" and no further thought is given to the issue of hostility. There are no doubts that this approach is wrong. Disability hate crimes may be one-off incidents, or systematic abuse that may continue even for years. ${ }^{54}$ There are issues that need attention.

First of all, disability hate crimes (compared to other kinds of hate crimes) seem more likely to depart from the expectation that the perpetrators are strangers. ${ }^{55}$ The reliance of the disabled person on the perpetrator unfortunately may mean that they feel reluctant or unwilling to report the crime. ${ }^{56}$ There are many cases examined in the literature on disability and abuse where repeat offenders situate themselves in positions of power over disabled people and exploit this dynamic in order to perpetrate criminal behavior. It is the relationship to the offender that is the most critical factor contributing to the under-reporting of disablist violence. Offender(s) are generally found to be known by the victims in some manner. At the same time, it contradicts conventional understandings of hate crime that construct this violence through the lens of "stranger danger."

52 B.T. McMahon, S.L. West, A.N. Lewis, A.J. Armstrong, J.C. Conway: Hate crimes and disability in America. "Rehabilitation Counseling Bulletin" 2004, no. 47 (2), p. 66; J. Petersilia, J. Foote, N.A. Crowell (ed.): Crime Victims with Developmental Disabilities. Report of a Workshop. Washington, D.C. 2001, p. 5.

${ }^{53}$ N. Hall: Hate crime. Crime and Society Series, 1st edn. Cullompton 2005.

${ }^{54}$ Disabled World, Disability Hate Crime Definition and Information, available at: https://www.disabled-world.com/disability/legal/disability-hate-crime.php [accessed 18 April 2020].

55 M. Sherry: Exploring Disability Hate Crimes. Paper for 16th Annual Meeting of the Society for Disability Studies, Bethesda, Maryland. June 12, 2003. "Review of Disability Studies", no. 1 (1), p. 52.

${ }^{56}$ It seems that there is a pattern of recidivism among certain care providers which entails repeated predatory behavior against disabled people that are under their care. For instance, one of the studies shows that 10 percent of disability caregivers were known to have had criminal histories for sexual assault, molestation, child abuse etc. Ibidem, p. 52. 
Secondly, to report hate-crime victimization to the police, a person with a disability must simultaneously report the crime and expose their disability as a potential motivation. ${ }^{57}$

Moreover, repeated victimization of disabled people is never seen as a form of hate crime. And yet such characteristics as repeat offenders against multiple victims, use of derogatory language and a high level of violence suggest that there may be unique dynamics which certain types of offenders exploit in committing disability hate crimes.

Signs of hate can include: words or symbols associated with hate, a history of hate crimes in the community, demeaning jokes about a particular group, the destruction of group symbols, a history of crimes against a group, and the presence of hate-group literature.

There are a multitude of disability hate crimes. One of the scariest examples is the assault against Eric Krochmaluk, ${ }^{58}$ an Oklahoma man with cerebral palsy who was taunted with epithets such as "You belong in the trash, you cripple" and who was then stuffed into a trash can, unable to call for help because of his speech impediment. ${ }^{59}$

Thirdly, if the investigating officers from law enforcement agencies do not have significant disability awareness, they may also fail to recognize a crime as a disability hate crime. Their lack of disability awareness unfortunately may also mean that they overlook evidence indicating the bias element of the crime. ${ }^{60} \mathrm{~A}$ law enforcement officer with limited disability awareness may not realize that AIDS fits the legal definition of a disability, and they may not report such a case as a disability hate crime.

It has long been recognized that the problem of disability hate crimes needs to be explored in far more detail, especially because with disability hate crimes there may be unique dynamics involved. There is no doubt that disability hate crimes need to be acknowledged, reported, and investigated thoroughly. What is important, the victims need appropriate support.

It is worth notice that many hate crimes are not reported at all. Reasons for the failure to report a hate crime could include the victim's shame, fear of not being believed, and/or fear of retaliation. That is why there is

57 R. Thorneycroft, N.L. Asquith: The Dark Figure of Disablist Violence. “The Howard Journal" 2015, no. 5 (54), p. 498; M. SHERry: Exploring ..., p. 56.

58 Ibidem.

59 This story was cited by the disability organization Protection and Advocacy. Ibidem, p. 56.

${ }^{60}$ For instance in 1999, the organization Consortium for Citizens with Disabilities has reported the case of a man living with AIDS who was attacked on a New York subway by a group of young women and men who screamed abuse at him, kicked him in the face, and left him with serious injuries. Ibidem, p. 56. 
a need to remove bureaucratic inefficiencies which impede the hate crime reporting process. Moreover, there are is a sequence of steps that should be taken to ensure the successful reporting and recording of hate crime:

- the victim understands a crime has been committed;

- the victim recognizes prejudice may have been a motivating (or aggravating) factor;

- the victim (or another person) solicits the police;

- the victim (or another person) informs the police of the prejudicial motivating factor;

- the Police acknowledge the prejudicial motivating factor;

- the Police document the prejudicial motivating factor, and apply appropriate human rights/hate-crime charges;

- the Police successfully record the incident of hate crime to the appropriate

- record-keeping authority. ${ }^{61}$

In order to effectively report disablist violence, a range of responses are required from within, and beyond, the criminal justice system. Policing organizations must also consider the way in which the structural and institutional cultures of policing shape how frontline officers and service staff engage with people with disability.

There are many important institutional strategies whose main aim is to improve the reporting environment with regard to hate crime. The first one is education and training. There is little doubt that police are better equipped to respond to reports of disablist violence when they are better educated and knowledgeable about its characteristics. Moreover, police officers should also become knowledgeable about all categories of hate crime. Silo-oriented disability awareness training is acceptable as an introductory step, but also a deeper understanding of cultural competence is required in order to meet the various arrays of disabled and vulnerable groups. A greater understanding of hate crime will also allow police officers to be more receptive to victim concerns, be more culturally and socially sensitive to victims' needs and to be better able to identify instances of hate crime. It also should be noted that increased cultural competency to deal with vulnerability in the criminal justice system, along with authentic, applied encounters with people with disability to increase awareness will help officers in their policing responsibilities,

${ }^{61}$ Of course, these steps would need to occur in sequence to ensure the proper reporting and recording of hate crime. If any step is not completed accurately, the system breaks down. Moreover, the likelihood that incidents will be properly reported or recorded diminishes. Each of these steps in the chain is, thus, subject to two types of error: failure of the system as a whole, or failure as it relates to the individual. Ibidem, p. 57; R. THORNEYCROFT, N.L. AsQuITH: The Dark Figure..., pp. 492-493. 
it can also enhance officers' abilities to problem-solve across a variety of victimization experiences. A greater knowledge of hate-crime victimization can increase the likelihood that disablist violence is identified and reported by victims and recorded correctly by police officers.

A second strategy is establishing specialist hate-crime policing units that can assist not just in strengthening reporting, but also in bolstering recording procedures. Specialist units, implemented as an interim measure, enable a dedicated group within the policing organization to be responsible for the investigation of all hate-crime cases. Specialist policing units with established and specialized referral networks can be better equipped to investigate and respond to instances of hate crime, as they will have been trained to do. Moreover, it is hoped that specialist hate crime policing units will improve the overall policing and investigative environment as they work proactively with frontline officers, vulnerable individuals and protected groups to prevent and respond appropriately respond to hate-crime victimization. It is worth noticing that specialist hate crime policing units will improve the overall capacity of a policing organization as an interim measure.

The other important thing is that third-party reporting offers a way for hate-crime victimization to be recorded by policing organizations even when victims are hesitant to report it themselves. Third-party reporting provides an opportunity to report a criminal incident to a communitybased organization whose primary responsibility is to support the victim and the victim's community. Unfortunately, many people with disability have had negative experiences with policing services, ranging from irrelevant and intrusive questions about their disability to more extreme examples where they have not been believed, or have been assessed as untrustworthy. It is worth notice that people with disability have a tendency to inform third parties about their victimization rather than inform the police. Formalizing third-party mechanisms appears to be a logical step in improving the reporting and recording of disablist violence. Advocacy organizations provide the social and welfare support required by victims of disablist violence. Building the capacity of these organizations to act on their communities' behalf in relation to seeking criminal justice redress requires them to be knowledgeable of hate crime. It also requires them to be equipped with the capacity to record instances of victimization. What is important, it requires these organizations to build strong referral and operational links with strategic, frontline policing units.

When these strategies are implemented, disability hate crimes are more likely to be reported, investigated in a culturally-competent manner, recorded in the crime systems correctly and referred to the courts in a more consistent manner. Each of these strategies can enhance policing organi- 
zations' abilities to monitor hate-crime victimization and trends in hate-crime offending. Then, trends will provide further insights into the steps that can be taken to enhance not just the reporting but also the prevention of disablist violence. But the most critical, long-term strategy is the investment in promoting disability equality. ${ }^{62}$

\section{Conclusions}

The United States of America has long been known as a cultural melting pot - a land of freedom in principle, where equality, self-expression, and the right to bear arms were integrated into the Constitution. Considering its history of racial inequality, the backlash of showing one's true colors and voicing opinions, and the seemingly endless incidences of violence, it is not surprising that many of the crimes committed are crimes against diversity; not just against individuals, but against categories of people, known as hate crimes. This article has defined and explored the parameters of hate crime, while acknowledging shortcomings in recognizing, reporting and responding to aggression and violence toward victims based on certain characteristics or affiliations.

Upon closer examination, there can be no doubt that certain steps have been taken by law enforcement and the legal profession to establish categorically-protected status, identify bias-motivated crime, and provide a framework for investigation and prosecution. In spite of the expansion of the legal infrastructure with regard to hate crime redress, including bills, laws and task forces, there seem to be limitations and shortcomings in both prevention and judicial recourse.

Dividing lines in the United States are not uncommon. From the borders and jurisdiction of each individual state, down to passionate support for local and regional sports teams, strong feelings of loyalty, likes and dislikes, are often formed at a young age. Just as good seeds planted early can bear good fruit, harbored feelings of ill will can eventually explode into violence. While this article does not explore the intricacies of who may be predisposed to commit a hate crime, the background scenarios of perpetrators, victims who provoked an attack, serial hate-crime offenders, and the effect that one's own marginalization has on being either a perpetrator or a victim, it does examine the current network of support and actions taken with regard to commonly targeted groups of victims based on race, religion, sexual orientation, and disability.

${ }^{62}$ R. Thorneycroft, N.L. Asquith: The Dark Figure..., pp. 500-502. 
As we begin to explore solutions, let us be reminded that crimes are committed by individuals with free will. While attempting to bring about their own form of justice, they are not ignorant of the penalty for violent crime. Prison exists for a reason, and may serve for some as the only deterrent for committing a hate crime, which is more often characterized by the element of brutality. With the foreknowledge that prison time is hard time, the penal system in the U.S. can still serve as a catalyst for reform.

Perhaps the best solution to ultimately eliminating hate crime lies in propagating very Judeo-Christian values whose erosion in the U.S. is what many feel may lead to the extremes of hate. Assuming that religious education assists in forming a solid foundation for dealing favorably with diversity, it is neither chosen by, nor available to everyone, not to mention the tuition costs. Despite the limitations to private Christian schooling, the better solution to the problem of hate crime in the U.S. may still lie in education, especially education based on Judeo-Christian values. Such education can develop a person's understanding of religious cultures, based on a loving God and what constitutes an acceptable response to those whose values and lifestyle choices are different from one's own. Impressionable youth may be favorably impacted by a mainstream curriculum that includes Cultural Awareness (and sensitivity) as a classroom subject. Through a combination of information, explanation, and enlightenment regarding specific lifestyle practices and differences, the virtue of acceptance and tolerance may become more readily and reasonably accepted curtailing the will to commit violent acts. Targeted coursework aimed at the root of racial, religious, sexual, and lifestyle differences may well prove more valuable than basic philosophy, sociology or ethics for both students as well as law enforcement officials. This sort of focused classroom education may be particularly beneficial for districts with demographics consisting almost entirely of one race, where misconceptions regarding "outsiders" are likely to be spawned or perpetuated.

It is important to mention that despite the plethora of repugnant hate-crime incidents that have yielded fear in certain communities and sown distrust among individuals, some of the most significant measures taken to promote racial equality and harmony have taken place within the United States. On a national level, affirmative action to assist minorities with employment has included outreach campaigns, targeted recruitment, development of employees, and employee support programs. Social service organizations continue to assist those in need, while numerous church outreaches continue to offer services to select groups and marginalized people. These efforts and responses have not just been spearheaded by mi- 
nority activists, but by citizens and good neighbors who share the outrage of inequality and are determined to freely offer brotherly help.

No matter how optimistic we are, no matter how inventive and visionary we become, we must be realistic and objective and realize that the danger of crime will never go away, and that it is our duty to identify the best measures on reducing crime. We must not think that being visionary and shaping a society without crime, a society where the rule of law and the respect of social values are a way of life for us all, is a utopia. A safe society, a higher life quality, should be our target and we should make everything in order to achieve it.

Mariana Mitra Ovidius (University of Constanta, Romania)

\section{Bibliography}

Barka M.B.: Religion, Religious Fanaticism and Hate Crimes in the United States. "Revue française d'études américaines" 2006, no. 110 (4).

CAmpbell S.: The Prevalence of Hate Crimes Motivated by Sexual Orientation in Florida after the U.S. Supreme Court Legalization of Same-Sex Marriages. Nova Southeastern University, A Dissertation Presented to the Department of Justice and Human Services of Nova Southeastern University in Fulfillment of the Requirement for the Degree of Doctor of Philosophy, 2019.

CHeng W., ICKes W., Kenworthy J.B.: The phenomenon of hate crimes in the United States. "Journal of Applied Social Psychology" 2013, no. 43 (4).

Cramer E.P.: Hate Crime Laws and Sexual Orientation. "The Journal of Sociology \& Social Welfare" 1999, no. 26 (3).

Dancygier R.M., Green D.P.: Hate Crime. In: The SAGE Handbook of Prejudice, Stereotyping and Discrimination. Eds. J.F. Dovidio, M. Hewstone, P. GLICK, V.M. Esses London, California, New Delhi, Singapore 2010.

Duimovich S.: A critique of the hate crimes prevention act regarding its protection of gays and lesbians (and now a private right could fix). "Southern California Review of Law and Social Justice" 2014, no. 23 (2).

ENTIN J.L.: Being the Government means (almost) never having say you're sorry: The Sam Sheppard case and the meaning of wrongful imprisonment. "Akron Law Review" 2005, no. 38.

Feagin J.R: Racist America: Roots, Current Realities, and Future Reparations. New York 2000.

Ghani N.: The Rise of Islamophobia in the United States: Patterns, Perpetrators, and Reactions. "American International Journal of Contemporary Research" 2018, no. 4 (8).

Grattet R., V. Jenness: Examining the Boundaries of Hate Crime Law: Disabilities and the Dilemma of Difference. "Journal of Criminal Law and Criminology" 2001, no. 93 (3). 
Green D.P., McFalls L.H., Smith J.K.: Hate Crime: An Emergent Research Agenda. “Annual Review of Sociology" 2001, no. 27 (1).

Hitman H., Harel D.: Hate Crimes-Methodological, Theoretical \& Empirical Difficulties-A Pragmatic \& Legal Overview. “Cultural and Religious Studies" 2016, no. 1.

JACOBS J.B., HENRY J.S.: The social construction of a hate crime epidemic. “The Journal of Criminal Law \& Criminology" 1996, no. 2 (86).

KidD J.D., WitTen T.M.: Transgender and Transsexual Identities: The Next Strange Fruit-Hate Crimes, Violence and Genocide Against the Global Trans Communities. "Journal of Hate Studies" 2007, no. 6 (1).

Lali V.: Hate Crimes. Theoretical paradigm. "Defondology”, 2016, no. 37-38.

LaWrence F.M.: The Hate Crimes/Hate Speech Paradox: Punishing Bias Crimes and Protecting Racist Speech. "Notre Dame Law Review" 1993, no. 68.

McMahon B.T., West S.L. Lewis A.N., Armstrong, A.J., Conway, J.P.: Hate crimes and disability in America. "Rehabilitation Counseling Bulletin" 2004, no. 47 (2).

Petersilia J., Foote J., Crowell N.A. (eds.): Crime Victims with Developmental Disabilities. Report of a Workshop. Washington, D.C. 2001.

Petrosino C.: Connecting the past to the future: hate crime in America. "Journal of Contemporary Criminal Justice" 1999, no. 15 (1).

PICKLES J.: LGBT Hate Crime: Promoting a Queer Agenda for Hate Crime Scholarship. "Journal of Hate Studies" 2019, no. 15 (1).

Relia K., Li Z., Cook S.H., Chunara R.: Race, Ethnicity and National Origin-based Discrimination in Social Media and Hate Crimes Across 100 U.S. Cities. Paper presented at 13th International Conference on Web and Social Media, ICWSM 2019, Munich, Germany.

Sherry M.: Exploring Disability Hate Crimes. Paper for 16th Annual Meeting of the Society for Disability Studies, Bethesda, Maryland. June 12, 2003. "Review of Disability Studies", no. 1 (1).

Shively M.: Study of Literature and Legislation on Hate Crime in America. Analytic Support Program Contract. Washington D.C. 2000.

Sun K.: The legal definition of hate crime and the hate offender's distorted cognitions. "Issues in Mental Health Nursing" 2006, no. 27 (6).

Thorneycroft R., Asquith N.L.: The Dark Figure of Disablist Violence. “The Howard Journal” 2015, no. 5 (54).

\section{Online sources}

Walters M.A., Paterson J., Brown R., McDonnell L.: Hate Crimes Against Trans People: Assessing Emotions, Behaviors, and Attitudes Toward Criminal Justice Agencies. "Journal of Interpersonal Violence”, available at: http://sro. sussex.ac.uk/id/eprint/67633/4/Hate\%20Crimes\%20Against $\% 20$ Trans $\% 20$ People\%20-\%20final\%20version\%20for\%20open\%20access.pdf [accessed 23 August 2020].

Verkhovsky A.: Criminal Law on Hate Crime, Incitement to Hatred and Hate Speech in OSCE Participating States, available at: https://www.sova-center.ru/ files/books/osce-laws-eng-16.pdf [accessed 4 April 2020]. 
Human Rights Watch: USA: "We Are Not the Enemy": Hate Crimes Against Arabs, Muslims, and Those Perceived to be Arab or Muslim after September 11. 14 November 2002, G1406, https://www.refworld.org/docid/45db101e2. html [accessed 4 April 2020].

Hate Crimes Violence. Hearing before the Committee on the Judiciary House of Representatives. One Hundred Sixth Congress. First Session, August 4th, 1999, Serial No 74, Washington, D.C. 2000.

Disabled World, Disability Hate Crime Definition and Information, available at: https://www.disabled-world.com/disability/legal/disability-hate-crime.php [accessed 18 April 2020]. 